\title{
ОСОБЛИВОСТІ ФОРМУВАННЯ УКРАЇНСЬКОЇ ПРАВООХОРОННОЇ ТЕРМІНОЛОГІЇ В ПЕРІОД КИЇВСЬКОЇ РУСІ
}

Аналіз наукових і лексикограбічних праць показав, що формування української правоохоронної термінології бере свій початок із часів появи первісного суспільства, коли з'явилася потреба захищати інтереси людей. Зазначено, що дослідження особливостей генези правоохоронного термінокомплексу в період Київської Русі на матеріалі історичних пам'яток дасть змогу унормувати правоохоронну термінологію як спеціалізовану систему понять, що забезпечує потреби фахової поліційної діяльності. Наголомено на важливості відтворення процесу зародження й розвитку правоохоронної термінології в діахронії для формування фахового тезаурусу сучасного поліцейського.

Ключові слова: українська правоохоронна термінологія (термінокомплекс), правоохоронні терміни, фахова поліційна діяльність, фаховий тезаурус сучасного поліцейського.

\section{Udovichenko L. Peculiarities of Formation of Ukrainian Law-Enforce-} ment Terminology in the Period of Kyivan Rus. Ukrainian law-enforcement terminology belongs to the most ancient professional systems of Ukrainian language, the origin of which began in a primitive society. It was created simultaneously with the necessity to protect social institutions, as evidenced by the first historical sources, such as "Ruska Pravda", (11-12 cent.), that is the first annalistic code of judicial laws of the ancient Rus-Ukraine and it represents all legal proceedings of the 11th century, safe protection measures, rights and interests of members of society; "The Primary Chronicle" (11-12 cent.), where remarkable historical events are chronologically recorded, and eligible facts from the lives of our ancestors are described and explained; "Galician-Volynian Chronicle" (13 cent.), that chronologically recorded the main events of origin, development and decline of the Galicia and Volhynia Kingdom. Lawenforcement terms are fixed by the earliest historical records, interchanged and operate alongside military and judicial terminology.

Taking into account the number of scientific studies, dedicated to military and legal language, scientists did not focus their attention namely on law-enforcement terminology as on an operational vocabulary of police service, that makes this study relevant in this area.

The aim of the scientific study is to select and describe law-enforcement terminology of the first written historical relics as a basis of social and state structure of our ancestors.

Formation of law-enforcement terminology is closely related to the beginning of life in society and social development, emergence of traditions, and rules 
of behavior in it, and thus the necessity to regulate such relations. The completeness of identified lexical and thematic groups of Ukrainian law-enforcement terminology clearly reflects the facts of life of the Kyivan Rus period. The study of the peculiarities of development of law-enforcement terminological complex within specified period on the material of historical relics will help to normalize the modern law-enforcement terminology as the specialized paradigm that meets the needs of the professional police activity and emphasizes the importance of rebuilding of the process of origin and development of law-enforcement terminology in diachrony for the formation of the professional thesaurus of modern police officers.

Key words: Ukrainian law-enforcement terminology (terminological complex), law-enforcement terms, professional police activities, professional thesaurus of modern police officer.

\section{Вступ}

Українська правоохоронна термінологія (УПТ) належить до найдавніших фахових систем української мови, зародження якої розпочалося ще з появою первісного суспільства, адже в будь-якому соціумі існують правила соціальної поведінки й особи, які їх порушують. Зважаючи на те, що Національна поліція України «служить суспільству шляхом забезпечення охорони прав і свобод людини, протидії злочинності, підтримання публічної безпеки й порядку» (Закон України «Про Національну поліцію»), аналізуючи сучасний поліційний термінокомплекс, можна стверджувати, що формування правоохоронних термінів нерозривно пов'язане зі становленням юридичної й військової терміносистем.

Військовий лексичний фонд ранньої доби вивчали Л. Батюк, А. Бурячок, А. Генсьорський, С. Гриценко, П. Ковалів; термінологію періоду козаччини - Я. Рибалка, Р. Сидоренко, Ф. Ткач, Г. Халимоненко; військову лексику в історичному розвитку - Т. Михайленко, Л. Туровська (Мурашко), зокрема ії тематичні групи - О. Андріянова, Я. Яремко, Н. Яценко, а новітні тенденції функціювання української військової терміносистеми - В. Жалай, Т. Линник, Т. Миронюк та ін. Історичний аспект генези, розвитку, проблем правничої термінології досліджували Н. Артикуца, М. Вербенєц, О. Каленюк, І. Кочан, М. Паночко, Н. Трач, Н. Шеремета, інші проблеми юридичного термінокомплексу - Л. Боярова, І. Гумовська, Г. Кожевников, А. Корж, П. Луньо, М. Любченко, Л. Наумовська, А. Піголкін, Ю. Прадід, Н. Руколянська, О. Сербенська, Б. Стецюк, С. Толста, І. Усенко, Л. Чулінда та інші. 
Військова лексика має солідний лексикографічний добуток, зокрема: В. Євтимович «Московсько-український словник для військових», С. та О. Якубські «Російсько-український словник військової термінології», А. Бурячок, М. Демський, Б. Якимович «Російськоукраїнський словник для військовиків», Ж. Безасьє, М. Науменко «Англійсько-українсько-французький словник зовнішніх зв'язків, стратегії та безпеки», В. Балабін, Р. Гардер «Українсько-французькоанглійський міжвидовий словник з тактики та логістики», І. Ольховой, М. Білан «Французько-український, українсько-французький словник основних термінів військово-повітряних сил країн НАТО», Л. Комарова, Є. Залєський «Українсько-англійський словник-довідник концептуальних понять», М. Вовк та ін. «Словник професійної термінології для майбутніх фахівців Національної гвардії України», Л. Туровська «Російсько-український та українсько-російський словник військової справи»; правнича лексика: Г. Онуфрієнко «Навчальний російсько-український словник фахової термінолексики для правників (понад 2200 терміноодиниць)», В. Гіжевський та ін. «Популярна юридична енциклопедія», Б. Шлоер та ін. «Німецькоукраїнсько-російський коментований словник 3 адміністративного права», В. Гончаренко «Юридичні терміни: тлумачний словник», В. Карабан «Англо-український юридичний словник», Л. Мисик «Українсько-англійський та англо-український словник правничої термінології», Г. Кучма «Термінологічний словник із загальної теорії держави та права (для молодших спеціалістів, бакалаврів, спеціалістів)», Ю. Шемшученко «Великий енциклопедичний юридичний словник», В. Гончаренко «Правознавство. Словник термінів», В. Муравйова, Л. Шевченко «Англо-український словник міжнародного, порівняльного і європейського права», О. Бєліков «Тлумачний словник найсучасніших юридичних термінів».

Незважаючи на чисельність наукових розвідок, присвячених військовій і юридичній лексиці, учені жодного разу не концентрували увагу саме на правоохоронній термінології як оперативному мовному фонді поліційної служби, що й становить актуальність досліджень у цьому напрямі.

Мета цієї наукової розвідки - виокремити й описати правоохоронну термінологію перших писемних історичних пам'яток, у яких сформовано підгрунтя соціального й державного устрою наших пращурів. 
Удовіченко Л. Г. Особливості формування української правоохоронної термінології в період Київської Русі

\section{Методи дослідження}

Для досягнення мети й реалізації поставлених завдань використовуємо загальнонаукові методи аналізу й синтезу як сукупність прийомів, операцій і дій з мисленнєвого роз'єднання об’єктів на складники, елементи, властивості (аналіз) й об’єднання їх у єдине ціле (синтез), метод спостереження як цілеспрямоване, планомірне сприйняття досліджуваних явищ; серед основних лінгвістичних методів дослідження обрано описовий як метод планомірної інвентаризації мовних одиниць і пояснення особливостей їх функціювання в синхронії; порівняльно-історичниц - для встановлення закономірностей розвитку тематичних груп лексем у діахронії, зіставний - для дослідження й опису мови через ії системне порівняння з іншою мовою з метою виявлення ії специфіки.

\section{Виклад основного матеріалу}

Досвід вивчення історії правоохоронних органів свідчить, що «провина в первісному суспільстві ставала наслідком порушення усталених правил і традицій, а реакцією був розшук та помста. Діяння, розшук винної особи та покарання в прямому та переносному сенсі повсякчас супроводжували життєдіяльність будь-якого суспільства. Тож цілком логічно можна зробити висновок про те, що прототипи сучасних правоохоронних органів існували ще в додержавному суспільстві» (Бондаренко, \& Литвиненко, 2018: 217). Якщо була потреба в правоохоронних діях, то, відповідно, особи, які цим займалися, послуговувалися певним термінологічним тезаурусом.

Правоохоронна термінологія почала створюватися одночасно з появою потреби захисту соціальних інститутів, про що свідчать перші історичні документи - основні джерела виникнення УПТ, тому дослідження іï формування доцільно розпочати з аналізу перших писемних пам'яток.

«Руська Правда» (XI-XII ст.) є першим літописним кодексом судових законів давньої Русі-України, що репрезентує всі процеси судочинства XI століття, заходи захисту безпеки, прав та інтересів членів суспільства, що і $є$ основною функцією правоохоронних органів.

У зазначеному збірнику законів наявні терміни на позначення офіиійних документів, зокрема: 'соудъ' (статут); назви карального спорядження, порівн.: 'мечь' (меч), 'батог' (батіг), 'чаша' (чаша), 'рог' 
(ріг), 'тыльсниа' (обух, тильна сторона предмета), 'ороужиє' (зброя); назви на позначення проведення слідства, слідчих дій та осіб, які ïx проводять, порівн.: 'познають' (упізнає), 'боудеть погоубиль' (загублено), 'изводъ' (стадія досудового процесу), 'кльтьныи', 'тать' (наклеп); назви, що стосуються судових процесів та осіб, які з ним пов'язані, порівн.: 'послух', 'истьца' (позивач), 'боудеть самъ почалъ' (зачинщик), 'виноватъ' (винний), 'тАжахъ' (справа), 'ръзъ’ (відсотки), 'Абетникъ' (обмовник, наклепник), 'тивунъ' (суддя, чиновник), 'помиловати' (помилувати), 'соборъ' (збори, суд), 'судъ' (судити); назви злочинів і правопорушень та осіб, які їх здійснюють, порівн.: 'головник' (вбивця, злочинець), 'разбоиник' (розбійник), 'мьстА' (кровна помста), 'разбои' (розбій), 'боудеть оубиль' (вчинив убивство), 'оубьють' (убити), 'татбь' (злодійство), 'оутнеть' (вкрасти), 'обидоа' (кривда), 'вина' (провина), 'синь' (синець), 'свадь' (сварка), 'боудеть крало’ (украдено), 'съкрыютьсA' (ховається), 'погоубіти’ (загубити), 'оукрадено' (украдено), 'погыбло’ (пропало), 'хоронилъ' (зберігав), 'кръвавъ моуже' (закривавлена людина), 'коневыи тать' (конокрад), 'тать' (крадій), 'мертвецъ' (труп), 'мечникъ' (мечник); назви на позначення покарань за правопорушення, порівн.: 'см(е)рть' (смерть), 'дикоуа вира' (штраф за злочин), 'дикоуа випа' (ув'язнення, вигнання чи вислання), 'казнить' (карати), 'продаже' (плата князеві за вчинену провину), 'възищеть' (стягнути); назви, пов'язані з інститутом свідків, порівн.: 'видок’ (свідок), 'оклеветающего' (обмовник), 'клеветы', 'кльпалъ', 'поклепь' (наклеп) тощо (Руська Правда).

«Повість минулих літ» (XI-XII ст.) є важливою писемною пам'яткою Київської Русі, де хронологічно зафіксовано визначні історичні події, правочинні факти з життя наших пращурів, описано й роз'яснено їх, що становить інтерес в аспекті дослідження процесу формування УПТ.

Літопис фіксує терміноназви офіційних документів, зокрема: 'законъ' (закон), 'устав' (статут), 'харотья' (хартія); назви карального спорядження, порівн.: 'оружье' (зброя), 'мечъ' (меч), 'копье' (спис), 'ножь' (ніж), 'лукъ' (лук); назви на позначення проведення слідства, слідчих дій та осіб, які їх проводять, порівн.: 'имЂчнаго' (поїмка), 'искушения' (слідство), 'держимъ будеть' (буде затриманий); назви, що стосуються судових процесів та осіб, які з ним пов'язані, порівн.: 'створивый’ (винний); 'урядъ положиша' (укласти договір), 
'дЂржится тяжи’ (перебуває під судом), 'створити миръ' (укласти мирний договір), 'утвЂржение' (затвердження), 'тяжа' (суд), 'судяй' (судити); назви злочинів і правопорушенв та осіб, щзо їх здійснююmb, порівн.: 'убивство' (убивство), 'убивати' (убивати), 'насилье' (насильство), 'татьба' (крадіжка), 'мучения' (побої), 'проказа' (злодійство), ‘разбоевЂ’ (розбої), ‘против’ (опір), ‘ходити’ (нападати), 'мертвЂць' (труп), 'погыбоша' (загинули), 'поемше талия своя’ (забрали своїх заручників), 'зарЂзанъ’ (зарізаний), 'разбойници’ (розбійники), 'полонъ' (полон), 'злобъ' (злочин); назви на позначення покарань за правопорушення, порівн.: 'казнь' (кара), 'епитЂмьеа' (покарання); назви, пов'язані з інститутом свідків, порівн.: 'клеветати' (обмовляти) тощо (Повість минулих літ).

У «Галицько-Волинському літописі» (XIII ст.) хронологічно зафіксовано найголовніші події виникнення, розвитку й занепаду Галицько-Волинського князівства, що $є$ важливим для наукового аналізу УПТ. Зокрема, ми виокремили такі тематичні групи УПТ: терміноназви офіційних документів, порівн.: 'законъ' (закон), 'грамота' (грамота у значенні документ); назви карального спорядження, порівн.: 'шелом' (шолом), 'мечь' (меч), 'копье' (спис), 'самострЂлы' (самостріли); назви на позначення проведення слідства, слідих дій та осіб, які їх проводять, порівн.: 'обличену' (викрили), 'утекши' (утікаючи), ‘бЂжавша' (яка втекла), 'бЂгаше’ (втікати), 'пустиста’ (відпустити), 'изимаша' (захопити), 'нЂсть противяся’ (чинити спротив), 'жива' (живий), 'спасена' (врятована), 'грозу подавая' (погрожувати); назви, що стосуються судових процесів та осіб, які з ним пов'язані, порівн.: 'свЂтъ створи' (провести нараду), 'присяга' (присяга), 'беззаконье’ (беззаконня), 'рЂчих’ (переговори), 'показа’ (доказувати); назви злочинів і правопорушень та осіб, які їх здійснюють, порівн.: 'убьена' (убито), 'убьенъ' (убитий), 'избьють' (убити), 'убиства' (убивство), 'разграбиша' (пограбували), ‘бися’ (битися), 'избити' (побити), 'избитье' (побиття), 'украль' (викрав), 'застрЂли' (застрелити), 'застрЂленъ' (застрелений), 'стрЂляющимъ' (стріляючи), 'исЂчени' (порубані), ‘Ђхавъ' (пограбував), 'плЂнить' (грабувати), 'воеваша’ (спустошити), 'томитель' (мучитель), ‘востания’ (заворушення), 'мятежъ' (заколот), 'могылЂ' (могила), 'тЂло', 'телеси' (тіло), 'трубья' (трупи), 'телесъ мертвих' (тіла мертвих), 'стрЂлци' (стрільці), 'рана' (рана), 'рана' (удар), 'противныхъ’ (супротивник), 'затворишася’ 
(здалися), 'возбиста' (побили), 'свЂтЂ' (у змові); назви на позначення покарань за правопорушення, порівн.: 'изгнаньи' (вигнання), 'повЂшение' (повішання), 'мучену' (тортури), 'мьсть' (помста), 'главу сосЂкоша' (відрубати голову); назви, пов'язані з інститутом свідків, порівн.: 'послухъ' (свідок) тощо (Галицько-Волинський літопис).

\section{Висновки}

Отже, становлення УПТ як самостійної групи починається 3 давніх часів; правоохоронні терміни, зафіксовані найдавнішими історичними джерелами, функціюють поряд з військовими і юридичними. Формування правоохоронного термінокомплексу тісно пов'язане із зародженням та розвитком суспільства, появою традицій і правил поведінки в ньому й, відповідно, потреби регулювання цих відносин.

Наповненість виокремлених лексико-тематичних групи УПТ яскраво відображає реалії життя періоду Київської Русі, зокрема писемні пам'ятки послідовно фіксують терміноназви офіційних документів, назви на позначення проведення слідства, слідчих дій та осіб, які їх проводять, а також такі, що стосуються судових процесів та осіб, з ними пов'язаних, назви злочинів і правопорушень та осіб, які їх здійснюють, назви на позначення покарань за правопорушення, зброї та ії частин, карального спорядження, а також назви, пов’язані з інститутом свідків. У зазначених писемних пам'ятках не простежуємо термінів на позначення правоохоронних структурних одиниць і назв установ, які здійснюють правоохоронні заходи, що свідчить про відсутність таких як самостійних у громадському житті українського суспільства в ті часи. Відповідно не репрезентовано й терміноназви на позначення елементів екіпірування зазначених органів, їнього однострою та звань.

Перспективою є подальше дослідження УПТ в діахронії, розроблення концепції сучасного словника української правоохоронної термінології.

\section{ЛІТЕРАТУРА}

1. Бондаренко О. С., \& Литвиненко Т. О. (2018). Історичний розвиток правоохоронних органів: досвід США, Великобританії та України. Молодий вчений, 10 (62), 216-222. 2. Галицько-Волинський літопис. Узято з http://litopys.org.ua/links/galvol. htm. 3. Закон України «Про Національну поліцію». Узято з https://zakon.rada.gov.ua/ 
laws/show/580-19\#Text. 4. Повість минулих літ. Узято з http://itopys.org.ua/pvlyar/yar. htm. 5. Руська Правда. Узято з http://litopys.org.ua/yushkov/yu04.htm.

\section{REFERENCES}

1. Bondarenko, O. S., \& Lytvynenko, T. O. (2018) Istorychnyi rozvytok pravookhoronnykh orhaniv: dosvid SShA, Velykobrytanii ta Ukrainy [Historical development of law enforcement agencies: the experience of the USA, Great Britain and Ukraine]. Molodyi vchenyi - Young scientist, 10 (62), 216-222 [in Ukrainian]. 2. Halytsko-Volynskyi litopys [Galician-Volyn chronicle]. Retrieved from http://litopys.org.ua/links/galvol.htm [in Ukrainian]. 3. Zakon Ukrainy "Pro Natsionalnu politsiiu» [Law of Ukraine "On the National Police»]. Retrieved from https://zakon.rada.gov.ua/laws/show/580-19\#Text [in Ukrainian]. 4. Povist mynulykh lit [A story of the past years]. Retrieved from http://litopys. org.ua/pvlyar/yar.htm [in Ukrainian]. 5. Ruska Pravda [Russian Truth]. Retrieved from http://litopys.org.ua/yushkov/yu04.htm [in Ukrainian].

Удовіченко Лілія Геннадіївна - аспірантка кафедри української мови, Харківський національний педагогічний університет імені Г. С. Сковороди; вул. Валентинівська, 2, м. Харків, 61168, Україна.

Tel.: +38-095-160-89-46

E-mail: vorotnikova225@gmail.com

https://orcid.org/0000-0001-5953-2923

Udovichenko Liliia Hennadiivna - Postgraduate Student at the Department of Ukrainian Language, H. S. Skovoroda Kharkiv National Pedagogical University; Valentynivska Str. 2, Kharkiv, 61168, Ukraine.

Надійшла до редакції 28 серпня 2020 року

\section{CITATION}

ДСТУ 8302:2015: Удовіченко Л. Г. Особливості формування української правоохоронної термінології в період Київської Русі. Лінгвістичні дослідження: зб. наук. пр. Харк. нац. пед. ун-ту імені Г. С. Сковороди. Харків, 2020. Вип. 53. С. 222-229. DOI https://doi.org/10.34142/23127546.2020.53.20

APA: Удовіченко, Л. Г. (2020). Особливості формування української правоохоронної термінології в період Київської Русі. Лінгвістичні дослідження, 53, 222-229. DOI: https://doi.org/10.34142/23127546.2020.53.20 